\title{
Study of consumer buying behaviour for wine with special reference to Sula vineyards
}

V.A. VIKHE, T.B. CHAVAN, V.N. ANAP, G.B. LABADE AND N.S. CHAVAN

Received : 26.06.2014; Revised : 20.08.2014; Accepted : 01.09.2014

\begin{abstract}
The per capita consumption of wine in India is only $10 \mathrm{ml}$ per annum as against 100 litres per year in Argentina and 65 litres in the European countries. Wine contains natural antioxidants that increase the life. Drinking of wine increases blood circulation that results into efficiency of working and decreases the tensions. Wine also contains mineral components that increase immunity power. So, it was felt necessary to study the consumer buying behaviour for wine with special reference to Sula vineyards. The findings of the study showed that majority of the consumers know about brand name and consider taste of the wine, while most preferred quality and only least think about the price of the wine. It was noted that White and Red wine have more demand in Nashik market. Sula vineyards has the most demand in Nashik market compared to its competitors. Through the study, it is reflected that customers are satisfied about the Sula product, its quality and service.
\end{abstract}

KEY WORDS : Sula, Wine, Buying behaviour

How to cite this paper : Vikhe, V.A., Chavan, T.B., Anap, V.N., Labade, G.B. and Chavan, N.S. (2014). Study of consumer buying behaviour for wine with special reference to sula vineyards. Internat. J. Com. \& Bus. Manage., 7(2) : 320-324.

\section{MEMBERS OF THE RESEARCH FORUM}

Correspondence to:

V.A. VIKHE, College of Agriculture Business Management, Loni, AHMEDNAGAR (M.S.) INDIA

Email: vijayvikhe11@gmail.com

Authors' affiliations:

T.B. CHAVAN, Mahatma Gandhi Mission, Krishi Vigyan Kendra, Gandheli, AURANGABAD (M.S.) INDIA

V.N. ANAP AND G.B. LABADE, College of Agriculture, Loni, AHMEDNAGAR (M.S.) INDIA

N.S. CHAVAN, Mahatma Gandhi Mission College of Agricultural Biotechnology, AURANGABAD (M.S.) INDIA 